\title{
Muscle-eye-brain disease with bilateral multicystic leucodystrophy
}

INSERM

\section{Source}

INSERM. (1999). Orphanet: an online rare disease and orphan drug data base. Muscleeye-brain disease with bilateral multicystic leucodystrophy. ORPHA:370997

A rare, genetic, congenital muscular alpha-dystrog lycanopathy with brain and eye anomalies disease characterized by a severe muscle-eye-brain disease-like phenotype associated with intellectual disability, muscular dystrophy, macrocephaly and extended bilateral multicystic white matter disease. 